\title{
Improving Student's Social solidarity Value Awareness through Learning Community-Based Mentoring
}

\author{
Laili Mufatakhah, Triana Rejekiningsih, Triyanto
}

\begin{abstract}
This research was attempted to analyze the concept of the integrated Islamic school in improving student's social solidarity value awareness through student's learning community-based mentoring (called as Islamic Character Building or BinaPribadi Islam/BPI) conducted in Nur Hidayah Integrated Islamic Junior High School (SMPIT Nur Hidayah). This research applied qualitative research design by doing a case study on seventh, eighth, and ninth grade students. Based on the result of the analysis, it is found that the type of mentoring activity held by SMPIT NurHidayah is the type of mentoring using the coeval group approach guided by teachers. The applying of learning community of BPIuses seven continuous cycles; namely: inquiry, action research, data analysis, planning, action, reflection and evaluation. The improvement of students' solidarity value awareness in SMPIT Nur Hidayah of Surakarta is conducted through several BPI agendas; such as: observing environment (the activity to contemplate God's creations and its phenomenon), camping, rihlah/trip which is aimed to raise the character of understanding and caring among the students. Those activities are strengthened by raising the values of togetherness and not discriminating others (for example by making a futsal team randomly), raising the sense of belonging (for example by visiting friends who get sick), and helping friends who have problem in both academic and non-academic case.
\end{abstract}

Index Terms: Solidarity, Students, Mentoring, Learning Community, Islamic Character Building (Bina Pribadi Islam)

\section{INTRODUCTION}

The role of education as a reinforcer of a very fundamental and significant attitude of solidarity as well as the ultimate solution is greatly needed in dealing with current advancements in the field of science and technology. This is in line with Bill Joy's opinion [1], that one of the key important solutions needed to meet the challenges of science and technology is how to fully and correctly understand solidarity. According to The American Heritage Dictionary of the English Language that the principle of solidarity is defined as the unity of interests, goals, or sympathies between group members [2]. The same thing emphasized by Gidding (1855-1931) that psychological interpretation of social solidarity is an idea of individual's consciousness about avirtue or goodness [3]. Consciousness in the perspectives of individuals' consciousness in recognizing individuals or other human beings, being conscious also

Revised Manuscript Received on April 19, 2019.

Laili Mufatakhah, in Civics Education Department, Faculty of Teacher Training and Education, Sebelas Maret University, Surakarta, Indonesia.

Triana Rejekiningsih, Civics Education Department, Sebelas Maret University of Surakarta, Central Java, Indonesia.

Triyatno, Lecturer of Civics Education Department, Sebelas Maret, University of Surakarta, Central Java, Indonesia. enables the establishment of mutual social interaction; this will consequently reduce each person's individualistic attitude. The nature (individual moral values) and students' attitudes need to be developed maximally, thus each student independently will grow that consciousness within themselves [4].

School as an institution where almost every individual has attended school education, the school is expected to be able to transmit individual's consciousness about each student's values of social solidarity. Education is a conscious effort that has been planned to develop intelligence, in addition to students' social personality (Law RI No.20 of 2003 article 1 paragraph 1). This is in line with Chaplin's statement [5] that "learning is the acquisition of changes in attitudes that are relatively permanent or permanent as a result of training and experience". Consciousness internalized students in themselves contributes significantly to identifying values manifested within oneself and others [6]. Therefore character education is a fundamental human interest in developing the moral and values of the young generation [7]. In line with Costley's opinion, et al [8] that character education has become a fundamental need in this era. Given the academic learning process also participates in building children's success. It should be noted that children who easily empathize with others make them grow in noble character.

Integrated Islamic School Nur Hidayah Surakarta is a

private Islamic school that emphasizes character education in an integrated concept [9]. An integrated Islamic education institution was pioneered in Indonesia as an alternative challenge to the development of times such as juvenile delinquency, student brawls, the use of illegal drugs through forming modern religious-based educational institutions as a basis for moral inculcation that did not result in negative developments in the times [10].

At least there are currently 10,000 integrated Islamic schools incorporated in the Integrated Islamic School Network (JSIT) which are spread throughout the territory of Indonesia. The implementation of character education can be carried out on a number of programs, including Islamic mentoring activities which

aim to shape students' social attitudes, one of which is, being aware of the value of solidarity. According to Rusmiyanti, et al [11] Islamic mentoring is an activity of fostering youth students that takes place periodically with an 
interesting peer approach, effective as the formation of character and students with Islamic personality.

\section{REVIEW OF RELATED LITERATURE}

\section{A. Relevant Studies}

Boucher [12] examined the role of teachers in fostering solidarity between white teachers who teach black students from Africa in 2016. The results revealed that teachers created multicultural and multi-racial classrooms and sought to build interactions and relationships of solidarity with their students by explaining the history of their white skin. The difference between this research and the previous one is the focus of the research that was raised. The author reviews the strategy of inculcating values of solidarity through mentoring the learning community BPI (Islamic Personal Development) at the IT Nur Hidayah Junior High School of Surakarta.

Méndez, et al. [13], critically analyzed students' strengths in establishing their fellow solidarity in the EFL class (English class) lesson learned from Bogotá, Colombia in 2012. The results of this study revealed that the form of student solidarity strength was established in the English language class (EFL). The strength of solidarity was established as a manifestation of the attitude of students to protect helpless friends who were bullied by other friends. This solidarity arises from the desire of a group of students who are weak to defend themselves against those who do violence. The differentiating element of this research from the others lies in the mentoring of the learning community able to instill the values of solidarity in themselves, the students of Nur Hidayah Middle School IT Surakarta.

Quan-Mc Gimpsey, et al.[14] Examined the Concepts and Strategies of Early Education Teachers to Manage Children 'Closeness and care in the Class in 2015 [21]. The results of this study revealed that the closeness of teachers to children's groups was analyzed by revealing the solidarity domain consisting of three dimensions namely emotional solidarity, consensual solidarity, and functional solidarity, where emotional solidarity shows the most dominant level. This research shows that the importance of the teacher builds a relationship of emotional solidarity between students in the class. The teacher intentionally utilizes interaction with his students to instill emotional solidarity with each of his students. Thus, there are good emotional solidarity among the students. The difference between this research and other related researches conducted by those aforementioned authors lays on the developed relationship of solidarity with their fellow students through mentoring activities held by BPI learning community (Bina Pribadi Islam).

Thomas Torbjornsson and Lena Molin [15], about exploring solidarity attitudes among high school students in Sweden in 2015, involved twenty-two third-year students. The results of the research show that students do not recognize solidarity because the concept and case history of solidarity have never been raised in the class. Literally,students do not know that solidarity has important relationships to face future challenges that require shared values. The difference between this research and the research conducted by the author lies in the subject of research and the focus of the research. The author examines junior high school students and examines the mentoring strategies of the learning community in forming solidarity among students.5. Zhang and Chen [16] analyzed ethnic solidarity education in China in 2014. The result of this research is that the practice of solidarity education in China bears a resemblance to western multicultural education, however, it remains to have a unique characteristic of authentic Chinese education. The difference between this research and the research conducted by the author lies in the focus of the research, namely the author raised the issue of the character in the form of solidarity values for the students. Junior Highschoo IT of Nur Hidayah Surakarta through mentoring

the BPI learning community.

\section{B. $\quad$ Mentoring}

Mentoring is a significant sustaining education media. Which means that guidance aims to effectively affect the "self-propelling force" of an individual [17]. Mentoring has long been regarded as a retention strategy used for undergraduate students and it has been proven through research that learning assistance efforts have a positive impact on various student developments and academic results. Mentoring in education is divided into five types, namely: "(1) peer mentoring among middle scholars, high scholars, and college students; (2) cooperating teachers mentoring student teachers; (3) experts are mentoring the novice or early career teachers; (4) career mentoring of doctoral students by faculty; and (5) mentoring of tenure track faculty by senior faculty "(Austin, James R, 2018 page $6)$. The teacher is a mentor who is considered affective in providing mentoring for students. Teachers also articulated the qualities of effective mentors: invested, flexible, and responsive [19].Crisp et al [20] identified four main focus of monitoring, namely: (1) mentoring has a relationship that focuses on student growth and development which can be formed in various ways; (2) monitoring provides experiences that include broad support for professional support, students' careers and emotional support; (3) monitoring has a personal and reciprocal relationship; and (4) a mentor who has knowledge and a lot of experience can relatively have a good influence on their students.

\section{Learning Communities}

As For schools that wish to transform their environment as learning communities, it is necessary to refer to five indicators that should be fulfilled. The five indicators are (1) Raising awareness; (2) decision making; (3) the dream; (4) selection of priorities; and (5) Planning [21]. Schools as educational institutions must be able to increase awareness for all school stakeholders to identify the strengths and weaknesses of education in schools. Internalizing these two forces in establishing a better educational process in the future. Another important thing is determining the method of education chosen and the training that must be done by the school for school teachers and staffs. The next phase is making decisions about planning and implementing

Published By: 
community learning. With this decision making it is expected that community learning planning is an educational step that is jointly agreed upon by all educators and education staff. The decision making process is an induction to make a democratic decision. All members of the learning community (students, teaching staff, and management team) determine the target of educational achievement to be carried out during learning. This target is what one hope or dreams they want for school in the future. When a decision has been made, a priority choice of action is made to make it more relevant and effective with the targets and expectations that have been determined. Finally, a plan is made oriented as a guideline and direction in implementing the learning community. This is important so that community learning runs well and efficiently. Learning communities are projects that aim to foster students' social attitudes and are transformational education that combines science, projects to improve student academic achievement, build life skills to coexist with each other and have a high attitude of social solidarity. The concept of learning community is the most important factor in students' social life related to the teaching and learning process. In contrast to a collection of individuals, learning communities are a setting in which the community has mutual learning objectives, and shows concern for the learning of each individual member. The learning community becomes a forum that will encourage the learning process for each member. Shirley Hord [22] emphasizes that "Learning communities apply a cycle of continuous improvement to inquiry, action research, data analysis, planning implementation, reflection, and evaluation".

\section{METHODS}

This is a typical of case study research, where Meyer [23] refers to research that uses empirical evidence from one or more organizations and researchers try to study problems in their context. Data collection uses interviews, observation and documentation. Informants include: teachers and students from the initial class to the end class. Documentation data is obtained from the Indonesian quality standards of JSIT.

\section{FINDINGS AND DISCUSSION}

The mentoring activity held by the Junior High School IT of Nur Hidayah was a type of mentoring approach to peer groups with teacher guidance. This mentoring activity focuses on forming Islamic personal character of students especially to instill solidarity values of students at the Junior High School of the IT of Nur Hidayah Surakarta. A number of terms of solidarity values applied by this school in Surakarta are referred to as ukhuwah Islamiyah inauguration. These activities are commonly referred to as Islamic mentoring activities namely Islamic personal development (Bina Pribadi Islam, BPI).BPI Islamic mentoring is an education and fostering of Islamic religion in the form of study groups that are held regularly every week and are continuous. Each group consists of 5-10 members and is guided by a coach [24]. Someone who is a mentor in a mentoring group is those who are more knowledgeable for experience than their mentoring members or mentees. Peer mentors will be successful if they are able to become more familiar with the mentor and have the same view of community learning practices [25].

Mentoring of the BPI learning community at Junior High School IT of Nur Hidayah Surakarta:

Table 1. The cycle of mentoring the BPI learning community (Bina Pribadi Islam) students in the IT Junior High School Nur Hidayah of Surakarta.

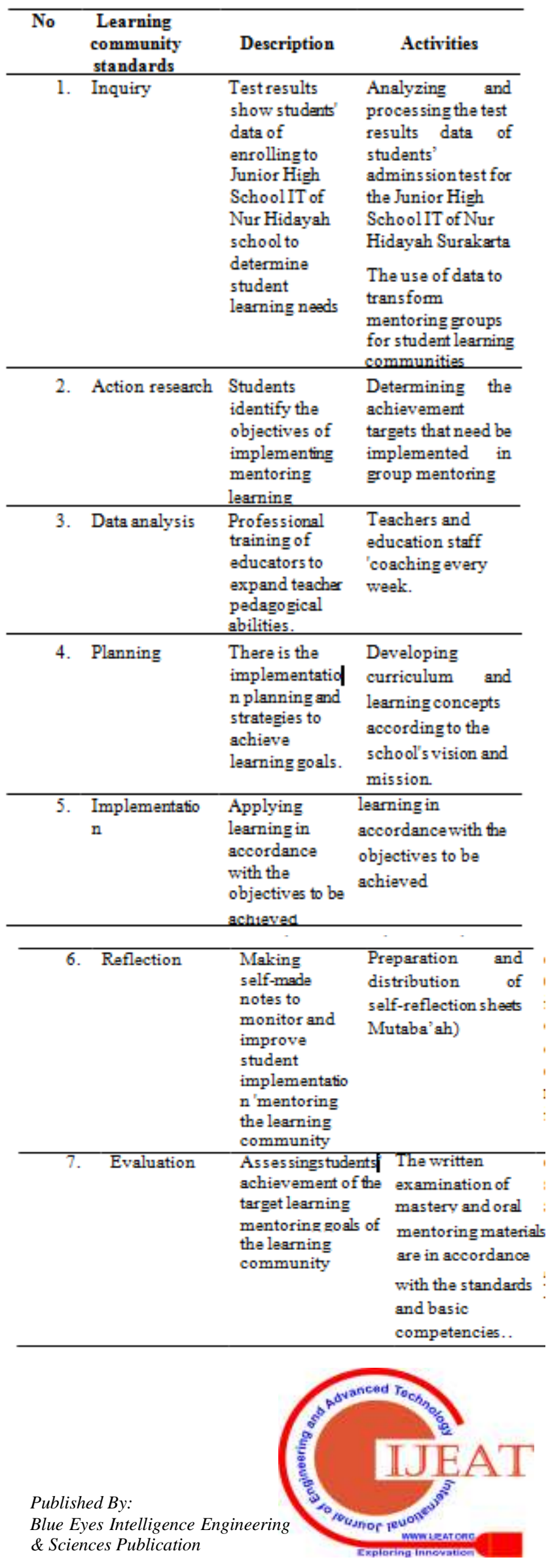


International Conference on Recents Advancements in Engineering and Technology (ICRAET-18) |15th and 16th March 2019|Siddhartha Institute of Technology \& Sciences, Telangana, India.

Mentoring activities are carried out in groups by randomly dividing groups based on test results. This is in accordance with the results of the interviews conducted to teachers of the Junior High School IT of Nur Hidayah

Surakarta that:"The grouping of mentoring is based on the results of students' enrolling tests (enrolling test for Senior High School IT of Nur Hidayah Surakarta). Test material includes the results of national exam scores, Islamic religious education, psychological tests, memorization of alquran, and interview tests....." (Teacher,F.M; 13-102018).The tests are carried out through several stages, namely the written test stage which contains tests of general knowledge and knowledge of blemishes, Al'quran reading tests, and the last is the interview test. Based on the results of the tests, students were divided into groups according to the test scores obtained. This aims to maintain the balance of knowledge and intelligence between group members. Thus, in each group there are members who are the smartest, excellent and less intelligent. This is done so that they help each other in accordance with the mastery of the knowledge they have. Indirectly the school deliberately expects students to get used to helping each other between friends or members of the learning community. In the end in the learning community in the Junior High School IT Nur Hidayah of Surakarta was able to shape the knowledge, attitudes and character of students in accordance with the expectations and vision of the school's mission. Learning community mentoring activities in Senior High School Nur Hidayah Surakarta IT are systematically arranged where in the mentoring curriculum that contains Mentors / teachers (Murobbi), students (Mutarobbi), institutions (schools), mentoring models (halaqoh, daurah, rihlah, tadabur, and muqoyyam) and there are indications of success. Mentoring activities are held once a week. The mentoring schedule for each learning community varies. For the 7 th class schedule, there will be a birthday, 8th grade on Monday and 9th on Thursday. Mentoring activities are conceptualized without reducing the schedule of students returning home. Because the schedule is conceptualized by means of inputting into the learning activities schedule at school.

The graduation standards that must be achieved by students in the mentoring activities of the BPI learning community are mature and noble personalities with competency achievements, among others: having ghirah (high inspiration) in their families; has ghirah (high inspiration) on his religion; do not cut off the conversation of others; do not pout with any sign; do not insult and belittle others; love little ones; great respect; bow down; keep secret; cover up the sins of others; love to invest and give alms; do not delay in carrying out the rights of other people and improve their appearance. The mentoring activities of the BPI learning community focus on forming the character of Islamic solidarity / ukhuwah among students. The methods of activities carried out including:
Table 2. The method use in mentoring students' learning community of the IT Junior High School, Nur Hidayah of Surakarta.

\begin{tabular}{|c|c|c|}
\hline Methods & Explanations & $\begin{array}{l}\text { Objectives of the } \\
\text { activity }\end{array}$ \\
\hline Tutorial & $\begin{array}{l}\text { The Private group } \\
\text { of the research } \\
\text { guidance }\end{array}$ & $\begin{array}{l}\text { Using discussion } \\
\text { methods is useful for } \\
\text { fostering a sense of } \\
\text { criticality, feeling of } \\
\text { respect and addressing } \\
\text { dissent. }\end{array}$ \\
\hline $\begin{array}{l}\text { Tafakur of } \\
\text { the nature } \\
\text { (thinking } \\
\text { about the } \\
\text { God's } \\
\text { creation) }\end{array}$ & $\begin{array}{l}\text { The activities } \\
\text { contemporer about } \\
\text { the contemplating } \\
\text { God's creation in } \\
\text { the form of } \\
\text { mountain climbing } \\
\text { beach walks. etc. }\end{array}$ & $\begin{array}{l}\text { Growing awareness of } \\
\text { God's creation, } \\
\text { awareness that humans } \\
\text { live side by sideandmust } \\
\text { live in harmony with } \\
\text { other creatures of God. }\end{array}$ \\
\hline Games & $\begin{array}{l}\text { Interesting group } \\
\text { games to avoid } \\
\text { students' saturated } \\
\text { learning. }\end{array}$ & $\begin{array}{l}\text { Make it easy for students } \\
\text { to understand the } \\
\text { material providedby the } \\
\text { coach in a way that is } \\
\text { more fun and not } \\
\text { pressing. }\end{array}$ \\
\hline $\begin{array}{l}\text { Mugoyyam } \\
\text { (camping) }\end{array}$ & $\begin{array}{l}\text { The joint camp } \\
\text { activities in } \\
\text { participants were } \\
\text { taken randomly } \\
\text { from grades seven } \\
\text { to nine. }\end{array}$ & $\begin{array}{l}\text { Fostering students to } \\
\text { actively participate in } \\
\text { groups, respect to fellow } \\
\text { group members and good } \\
\text { cooperation. }\end{array}$ \\
\hline
\end{tabular}

In addition to the method of activities above other things that are done in the learning community conducted by teachers and schools in shaping and improving students' values of solidarity, namely Futsal activities, visiting friends who suffer from illness (especially friends in a learning community), in addition to the reflection that how to spend the night at school. Various methods and types of activities are carried out in a fun and not boring way. This is evidenced by the typical activities carried out such as delivering the aforementioned, namely with activities that are not only class and saturate because they only learn from books.

Based on the results of interviews with students named Farel, Rizal, Afkar, Aik and Dorinta, BPI mentoring activities at Nur Hidayah Middle School are fun and very beneficial activities for students. Through this mentoring activity students feel that being someone who has a sense of caring and togethernesstowards each other is getting better and tighter. This activity is well-packaged by the teachers bearing the activities are not only about the material but are very well packaged so that students do not feel bored and burdened with BPI mentoring activities.

Based on the description above, the mentoring activities of the BPI learning community Junior High School TI of Nur Hidayah in the Surakarta is in accordance with the learning theory of behaviorism Pavlov proposed [26] that learning is a change in behavior, where students who have carried out learning activities will experience behavioral changes. The behavioral changes that occur in Junior Highs School IT of Nur Hidayah after the learning community mentoring is the establishment of students' personalities that hold solidarity each other, care and love for others. According to Nasution [27] that solidarity is a moral feeling oriented to fulfill the 
role expectations due to the principle including the mutual care, responsibility and cooperation.

The BPI (Bina Pribadi Islam) mentoring learning community at the IT Junior High School Nur Hidayah of Surakarta is a characteristic of the school in fostering / mentoring the students' characters, more specially in upholding solidarity among friends. This is as Amnur [28], explained that there are four elements of character education suggested by UNESCO, namely 1) learning to know, 2) learning to do, 3) learning to become learn to be, and 4) learn to live together. The first, second and third elements are more about forming human resources that have abilities in knowledge, attitudes and skills. This is evidenced by the competency standards that students must achieve through BPI mentoring. Whereas the fourth element is more towards character building related to mutual benefit, for example: honesty, responsibility, solidarity, and cooperation that is applied in various activities that have been designed in mentoring the BPI learning community.

The impact that the character education model through BPI mentoring in Junior High School IT of Nur Hidayah of Surakarta was felt in the long term. This is the as Creasy [29] suggests that character education is an applicable program to transform students into respectable, responsible, and contributing community members. According to Sukamto cited in Linda Sari Rambe, et al [30] said that in order to conduct character education, it is necessary to have powerful ideas that become the entrance to character education. The ideas of powerful ideas include: God, the world and me (the idea of challenging God, the world and me); Knowing oneself (understanding yourself); becoming a moral person (being a moral person); understanding and being understood along with others (able to understand and be understood); a sense of belonging (in collaboration with others); Strength drawing from the past; Dien for all times and places (consistent all the time and wherever you are); Caring for Allah's creation (concern for God's creatures); Making different; and taking the lead (taking something definite). Character education can be done through various approaches and various activities, including the intra-curricular and extracurricular activities. According to

M. Furqon, [31] strategies in the formation of character attitudes of students can be done in various ways, namely exemplary, planting discipline, habituation, creating a conducive atmosphere, and integration and internalization of morals.

\section{CONCLUSION}

Schools as educational institutions can at least be an alternative to the impact of the development of science and technology. It is not enough just to make students who have intellectual intelligence only, but also need to foster the spiritual and emotional intelligence of students well too. One way to deal with these challenges is to form student solidarity values. This is done as a filter for the negative impact of the digital era, for example egocentric behavior, not caring about others and individualistic. As for how to instill awareness of the values of student solidarity can be realized through forming community-based learning mentoring in schools.
The students' mentoring community learning as an effort to improve their values of solidarity in the IT Junior High School of Nur Hidayah was carried out through mentoring activities of the Islamic learning community of BPI (Islamic Personal Development) which was carried out through students' random grouping according to the level and results of their enrolling test. This typical mentoring activity of peer group approach is accompanied by a teacher guide. BPI Islamic learning community activities are one of the characteristics of character education strategies applied in the IT Senior High School of Nur Hidayah of Surakarta in shaping the character of students who have high values of solidarity with others.

The method used by BPI (Islamic Personal Development) aims to foster awareness in students of the values of solidarity, including tutorial methods (independent group tutoring such as discussions that are useful to foster a sense of criticality, respect and respond to differences of opinion), bearing tafakkur (fostering awareness of God's creation, awareness of humans living side by side). The implementation of BPI mentoring in the IT Junior High School of Nur Hidayah is carried out in accordance with inquiry processes, action reports, data analysis, planning, implementation, reflection and evaluation

\section{REFERENCES}

1. B. Joy. Why the future doesn't need us, 2000. Retrieved fromhttp://www.eirwwd.com/wired/archive/8.04/joy_prh tm

2. Raufelder, W.M. Bukowski and S.Mohr. Thick Description of the Teacher student Relationship in the Educational Context of School: Results of an Ethnographic Field Study. Journal of education and training studies, vol.1(2), 2013, pp.1-18, Retrieved form http://dx.doi.org/10.11114/jets.v1i2.1083.

3. H. Hankins. F.H. Giddings 1855-1931: Some Aspects of His Sociological Theory." American Journal of Sociology, vol.37, 1931, pp.349-3674.

4. H.J. Tuloli, \& D. E. Ismail. Pendidikan karakter: menjadikan manusia unggul. Yogyakarta: UII press, 2016.

5. J.P. Chaplin, Dictionary of Psycology. New York: Dell Publishing Co. Inc., 1972.

6. C. Boulder. Social Science Education Consortium Newsletter. Journal of Social Science Education Consortium, vol. 20, 1974),pp.7.

7. T. A Young. Hadaway, N.L Ward, A. Barbara (2013) International Children's Trade Books: Building Blocks for Character Education. Childhood Education, 89 (6), p. 379-386.

8. K.C Costly \& K.Harrington. Character Education: A Growing Need in American Schools. (Online

9. Submission), 2012.

10. S.M. Munawaroh, et al.Pendidikan karakter berbasis potensi diri di SMP IT Nur Hidayah Surakarta tahun pelajaran 2013/2014. (University research colloquium, 2015). ISSN 2407-9189

11. Suyatno. Sekolah Islam Terpadu; Filsafat, Ideologi, dan Tren Baru Pendidikan Islam di Indonesia. Jurnal Pendidikan Islam, vol. 2 (2), 2014, pp.355-377

12. Rusmiyanti, et al. Panduan Mentoring Agama Islam: Buku Materi Jilid 1. Jakarta: Departemen Pembinaan IQRO CLUB, 2003. 
13. Boucher, Michael Lee, Jr. More than an Ally: A Successful White Teacher Who Builds Solidarity with His African American Students. JournalUrban Education, vol.51, (1), 2016, pp. 82-107.

14. T. Méndez,\& A.García. Exploring Elementary Students Power and Solidarity Relations in an EFL Classroom (Exploración de las relaciones de poder y solidaridad entre estudiantes de primaria en la clase de inglés como lengua extranjera). Journal Issues in Teachers Professional Development, vol. 14 (1), 2012, pp. 173-185

15. Q.McGimpsey, Sharon; Marziliano, S.Carmen; Hassen, T.Gregory; Brown, A.Sandra; K.Leon. Early Education Teachers' Conceptualizations and Strategies for Managing Closeness with the Class in Child Care. Journal Teachers and Teaching: Theory and Practice, vol. 21, (5), 2015, pp.514-526.

16. T. Torbjornsson and L. Molin. In School We Have Not Time for the Future: Voices of Swedish Upper Secondary School Students about Solidarity and the Future. Journal International Research in Geographical and Environmental Education, vol.24 (4), 2015, pp. 338-354.

17. D. Zhang and L. Chen. Creating a Multicultural Curriculum in Han-Dominant Schools: The Policy and Practice of Ethnic Solidarity Education in China. Journal Comparative Education, vol.50, (4), 2014, pp. 400 - 416.

18. S. Khakwani, H. D. Aslam, M.S.Azhar, M.M. Mateen. Coaching and Mentoring For Enhanced Learning of Human Resources in Organizations: (Rapid Multiplication of Workplace Learning to Improve Individual Performance). Journal of Educational and Social Research, vol. 2, (1), 2012, pp. 257-266.

19. J. R. Austin, Take a Researcher to Lunch: Informal Mentoring for Researchers. Journal of Music Teacher Education, vol.28, 2018, pp. 6-9.

20. J.Ernst; Ericks, M. Deanna. Environmental education professional development for teachers: A study of the impact and influence of mentoring. Journal of Environmental Education, vol.49, (5), 2018, pp. 357-374.

21. G.Crisp, V. L. Baker, K. A.Griffin, L. G. Lunsford, \& M. J. Pifer, "Mentoring undergraduate students". ASHE Higher Education Report, vol.43, (1), 2017, pp.7-103. Retrived from https://doi.org/10.1002/aehe.2011721. Eramus

22. Program, Schools as Learning Communities in Europe: Successful Educational Actions for all (SEAS4ALL), 2015. Retrieved from https://seas4all.eu/.

23. S.M Hord, and P.Roy. Reach the highest standard in professional learning: Learning Communities. London, United Kingdom: Sage publication Asia-Pasific Pte. Ltd, 2014.

24. C. B. Meyer. A case study methodology. Norwegian School of Economics and Business Administration, 2001. https://doi.org/10.1177/1525822X010130040224.

25. M.Sarijun. Manajemen halaqoh efektif. Solo: Era adicitra intermedia, 2011.

26. S. L. Hessenauer, K. Law, Mentoring: A natural role for learning community faculty. Journal Learning Communities Research and Practic, vol. 5 (2), 3, 2017. https://washingtoncenter.evergreen.edu/lcrpjournal/vol5/i $\underline{\mathrm{ss} 2 / 3}$

27. M. Irham, \& Wiyani. Psikologi Pendidikan: Teori dan Aplikasi Dalam Proses Pembelajaran.Yogyakarta: ArRuzz Media, 2013.

28. Nasution, Solidaritas sosial dan Partisipasi Masyarakat Desa Transisi (Suatu Tinjauan Sosiologi). Malang UMM Press, 2009.

29. A.M. Amnur, Konfifurasi politik pendidikan nasional. Yogyakarta: Pustaka Fatima, 2007.

30. K.L Creasy, Is There a Place for Character Education? Pennsylvania: Slippery Rock University, 2008. http://dx.doi.org/10.2139/ssrn.114182330.
31. L.S. Rambe, et al. 2018.design of character education model in learning civics at state

32. Hidayatullah, Pendidikan Karakter: Membangun PeradabanBangsa. Surakarta: UNS Press \&Yuma Pustaka, 2010

\section{AUTHORS PROFILE}

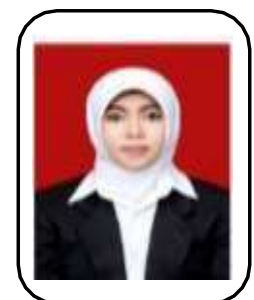

Laili Mufatakhah, is a student of masterprogram in Civics Education, faculty of teacher training and education, universities in Sebelas Maret University of Surakarta. She has been actively joining scientific forums and writers to several journals and proceedings. Among her articles are the strategies for handling victims of bullying at Homeschooling Kak Seto Solo (2017 national seminar journal); The content of Pancasila values in the 2013 curriculum book XI of students education nationality (2017 national proceedings); and the role of women's strategy in internalizing anti-corruption values through Saya Anti Korupsi (SPAK) (proceedings of the national seminar in 2018).

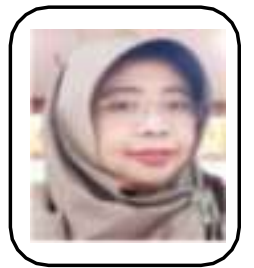

Dr. Triana Rejekiningsih, S.H., K.N., M.Pd. is a lecturer in Civics education department of Sebelas Maret University. She has completed her undergraduate education in 1998 from School of Law, Sebelas Maret University. Then graduated from her master's education at Gadjah Mada University in 2002, and completed her doctoral education at the Indonesian Education University in 2014. Dr. Triana Rejekiningsih has conducted a number of studies. She has actively participated in various researches at internal campus level and the Ministry of Research and Technology. Additionally, she also has actively published his writings in several internationally reputed journals.

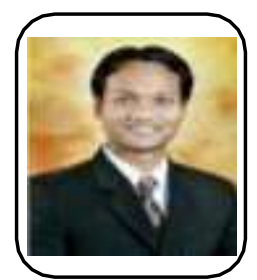

Dr. Triyanto, SH. M.Hum is a lecturer in Pancasila education and state law department of Sebelas Maret University. He has completed his undergraduate education in 2005 from School of Law, Sebelas Maret University. Then he completed his master's education at Gadjah Mada University in 2007, and completed his doctoral education at the Indonesian Education University in 2011. Dr. Triyanto has conducted a number of studies. He has actively participated in various researches at internal campus level and the Ministry of Research and Technology. Additionally, he also has actively published his writings in severalinternationally reputed journals. 